\title{
Norepinephrine and E139 Interactions on Epileptiform Activity in the Rat Hippocampus in vitro
}

\author{
Samuel B. Kombian ${ }^{a}$ Kethireddy V.V. Ananthalakshmi ${ }^{a}$ Ivan O. Edafiogho ${ }^{b}$ \\ Departments of applied Therapeutics and ${ }^{b}$ Pharmacy Practice, Faculty of Pharmacy, Kuwait University, Kuwait
}

\section{Key Words \\ Adrenergic mechanisms · Enaminones - Epilepsy • \\ Population spike $\cdot$ Spontaneous bursts}

\begin{abstract}
Objectives: We tested if E139, an anticonvulsant enaminone, interacts with norepinephrine (NE) to suppress population responses and chemically induced in vitro seizures in the rat hippocampus. Materials and Methods: Evoked field population spikes (PS) were recorded in the hippocampal CA1 area, and in vitro seizures were generated chemically using the zero $\mathrm{Mg}^{2+}$ model. Results: Low concentrations of E139 $(\leq 10 \mu \mathrm{M})$ reversibly inhibited PS amplitude while high concentrations ( $\geq 100 \mu \mathrm{M}$ ) enhanced them. For example, E139 $(10 \mu \mathrm{M})$ depressed the PS amplitude by $-23.9 \pm 2.3 \%$, while $1 \mathrm{~mm}$ caused an enhancement. NE also depressed the PS by $-34.5 \pm 6.0 \%$ and prevented E139 from subsequently depressing the PS amplitude. UK 14304, a selective $\alpha_{2}$-adrenoceptor agonist, also depressed the PS amplitude by $-32.6 \pm$ 9.4\% and occluded E139 suppression. NE suppression of PS was blocked by phentolamine and yohimbine which also blocked the effect of E139. Prazosin, a selective $\alpha_{1}$-adrenoceptor antagonist, did not block NE $(-24.8 \pm 6.9 \%)$ or E139 $(-29.7 \pm 6.1 \%)$ effects. Zero $\mathrm{Mg}^{2+}$ buffer transformed a single PS to multiple spikes (MS; 3-8 spikes) and also induced spontaneous bursts (SB; $5-20 / \mathrm{min})$. NE suppressed the number of
\end{abstract}

MS from $5.6 \pm 0.3$ to $3.8 \pm 0.2$. At its peak effect, E139 was able to further suppress the number of MS to $3.0 \pm 0.3$. Yohimbine did not change the number of MS but blocked the NE- and E139-induced suppression of MS. SB frequency was suppressed by NE (-60.8 $\pm 11.7 \%)$ which occluded E139 effects. Finally, SB were reversibly abolished by yohimbine (-94.5 \pm 11.7\%). Conclusion: E139 suppressed population responses and in vitro epileptiform activity by both adrenergic and non-adrenergic mechanisms.

Copyright $\odot 2008$ S. Karger AG, Base

\section{Introduction}

Structural analogues of some anilino-enaminones have demonstrated in vivo anticonvulsant actions $[1,2]$ which are now clearly supported by in vitro evidence at the cellular and network levels [3-5]. Multiple mechanisms of action may underlie these actions of anilino-enaminones to suppress seizures. Based on electrophysiological recordings and occlusion experiments, they were postulated to enhance extracellular $\gamma$-aminobutyric acid (GABA) [3]. Pharmacological evidence has also been published that shows that enaminones directly suppress postsynaptic sodium currents [4] and modulate adrenergic antiseizure actions [6]. In the latter case, E139, a prototypical anilino-enaminone, was reported to act as a pu-

\section{KARGER}

Fax +4161306 1234

E-Mail karger@karger.ch

www.karger.com (c) 2008 S. Karger AG, Basel

$1011-7571 / 08 / 0175-0365 \$ 24.50 / 0$

Accessible online at:

www.karger.com/mpp
Dr. Samuel B. Kombian

Department of Applied Therapeutics

Faculty of Pharmacy, Kuwait University

PO Box 24923, Safat 13110 (Kuwait)

Tel. +965 498 6916, Fax +965 534 2807, E-Mail kombian@hsc.edu.kw 
tative agonist of $\alpha_{2}$-adrenoceptors through which it enhanced extracellular GABA levels. Norepinephrine (NE), the main endogenous ligand for these receptors in the central nervous system, is reported to have both convulsant and anticonvulsant properties [7-15]. These proconvulsant and anticonvulsant effects of NE are thought to depend on the receptor subtype that is activated $[12,16]$ and possibly the extracellular concentration of NE [17, 18]. The majority of reports appear to support an anticonvulsant role of NE. For example chemical depletion of NE by 6-hydroxydopamine is known to facilitate kindling $[19,20]$; genetically engineered mice lacking dopamine $\beta$-hydroxylase, an enzyme responsible for converting dopamine to NE, have increased vulnerability to seizure stimuli [10], and knockout mice lacking the NE transporter are more vulnerable to seizures [14]. Pharmacological studies largely support this anticonvulsant role of $\mathrm{NE}[12,21-23]$. However, proconvulsant actions of NE have also been reported using various research approaches $[16,17,24,25]$.

By recording whole-cell currents from single cells, we recently reported that NE-induced depression of excitatory synaptic transmission occluded that induced by E139 [6] suggesting that E139 may employ mechanisms similar to NE to produce its reported in vivo anticonvulsant effects. In a recent study, we also showed that E139 suppresses electrically and chemically induced epileptiform activity recorded in rat hippocampal slices [5]. In this study, we investigated if, similar to the above interaction at the single-cell level, E139 employed adrenergic mechanisms to suppress population and network responses in the hippocampus that are more representative of seizures.

\section{Materials and Methods}

\section{Animal Experiments}

All animals used in this study were male Sprague-Dawley rats supplied by Kuwait University Animal Resource Centre. All experiments were done in accordance with guidelines on humane handling of experimental animals as established by the Canadian Council on Animal Care. The procedures were designed to minimize animal suffering, and the smallest number of animals necessary to produce the required results was used.

\section{Slice Preparation}

Extracellular electrophysiological experiments were performed in coronal hippocampal slices generated from rats (75$150 \mathrm{~g}$ ) using previously published techniques and methods [26]. Briefly, each rat was deeply anaesthetized with halothane and killed by quick decapitation. The brain was quickly removed and placed in ice-cold $\left(4^{\circ} \mathrm{C}\right)$ artificial cerebrospinal fluid (aCSF) bub- bled continuously with $95 \% \mathrm{O}_{2}$ and $5 \% \mathrm{CO}_{2}$ (carbogen). Coronal slices $(400 \mu \mathrm{m})$ of the forebrain containing the hippocampus were cut from a block of brain tissue in ice-cold aCSF using an Electron Microscopy Sciences (Hatfield, Pa., USA) OTS-4000 tissue slicer. Prior to recording, slices were incubated for $1 \mathrm{~h}$ in aCSF that was continuously bubbled with carbogen at room temperature. Most cortical and basal brain tissues were carefully trimmed off slices, and the remaining block containing the hippocampal formation was suspended on a nylon mesh in a 500- $\mu$ l capacity recording chamber. The bath temperature was tightly maintained at 29$31^{\circ} \mathrm{C}$ to ensure that changes in responses were not due to variation in temperature [27]. Slices were perfused at a flow rate of 2-3 ml/ min with aCSF that was bubbled with carbogen. An extracellular field recording glass electrode (3-15 $\mathrm{M} \Omega$ ) filled with $3 \mathrm{M} \mathrm{NaCl}$ was placed in the stratum pyramidale of area CA1, and a bipolar stimulating electrode was placed in the stratum radiatum near area CA1 to activate Schaffer collateral/commissural fibres.

Population Spikes and Chemically Induced in vitro Seizures

The composition of the aCSF used for dissection, storage and population spike (PS) recordings was (in $\mathrm{mM}$ ): $120 \mathrm{NaCl}, 3.3 \mathrm{KCl}$, $1.2 \mathrm{MgSO}_{4}, 1.3 \mathrm{CaCl}_{2}, 1.23 \mathrm{NaHPO}_{4}, 25 \mathrm{NaHCO}_{3}$ and $10 \mathrm{D}$-glucose. First, a single PS was recorded by stimulating the appropriate afferents and moving the field recording electrode around until an optimal PS could be recorded. For recording of epileptiform-type multiple PS and spontaneously occurring epileptiform-type activity referred to as spontaneous bursts (SB), the zero $\mathrm{Mg}^{2+}$ model employed by Klapstein and Colmers [26] was used. We chose this model because, in our laboratory, it was more reliable than picrotoxin in generating in vitro seizure-like activity [5]. Furthermore the synaptic and anticonvulsant actions of NE have been reported in some studies to be independent of the GABAergic system $[18,28]$. In this model, the omission of $\mathrm{Mg}^{2+}$ from the buffer results in the removal of the voltage-dependent $\mathrm{Mg}^{2+}$ block of N-methyl-D-aspartate receptors [29]. This transformed a single PS following one afferent stimulation to multiple spikes $[5,30,31]$. Furthermore, SB that are thought to represent interictal events also accompany the multiple spikes (MS). Briefly, the perfusing solution was changed to zero $\mathrm{Mg}^{2+}$ aCSF (aCSF with the $\mathrm{MgSO}_{4}$ omitted), and then the slice was monitored over a period of 10-20 min for the development of epileptiform-type multiple PS following stimulation and SB (independent of stimulation). All control responses were monitored and shown to be stable for at least 30 min prior to the application of a drug.

\section{Data Acquisition, Analysis and Statistics}

All recordings were made using an Axopatch 1D amplifier and pClamp software (Clampex 8; Molecular Devices, Sunnyvale, Calif., USA) in current clamp mode at sampling rates of $50 \mathrm{kHz}$, filtered at $10 \mathrm{kHz}$, digitized and stored for off-line analysis. For PS, each stored trace was an average of 5 successively triggered responses elicited at 10 -second intervals. The amplitude of the PS was measured from the peak of the positive going wave to the tip of the negative going wave. As well, the initial rising slope (from zero to just before the compound action potential) was also analysed in some experiments. For quantifying epileptiform activity, the number of spikes occurring following the stimulation was counted, and the number of SB occurring in $1 \mathrm{~min}$, recorded in gap-free mode, was counted and used as the frequency. The duration of SB was measured and the number of spikes in each SB was 
counted. Drugs were perfused for 5-30 min depending on the experiment, and these are specified in the results section. All data are expressed as mean \pm standard error. Statistical significance of all measures was determined using Kruskal-Wallis multiple comparison followed by Student's t test (paired or unpaired where appropriate) and was considered significant at $\mathrm{p} \leq 0.05$ using Sigmastat ${ }^{\circledR}$ (Systat Software Inc., San Jose, Calif., USA). PS amplitudes were normalized by taking the mean of 4-5 responses prior to drug application and dividing the rest of the values by this mean. These values were used for average plots and bar graphs. All graphical representations were done using Sigmaplot ${ }^{\circledR}$ (Systat Software Inc.), and Coreldraw ${ }^{\circledR}$ (Corel Corp., Ottawa, Canada) softwares.

\section{Chemicals and Drugs}

The enaminone E139 was synthesized in house, characterized $[1,32]$ and dissolved in dimethyl sulphoxide. Stock solutions of 10 $\mathrm{mM}$ were prepared, aliquoted and stored at $-20^{\circ} \mathrm{C}$ and used within 3 weeks. All routine laboratory salts and tetrodotoxin (TTX), NE, phentolamine, yohimbine and prazosin were from SigmaAldrich Chemie GmbH (Steinheim, Germany). 5-Bromo-6-(2imidazolin-2-ylamino)quinoxaline (UK 14304) was obtained from Tocris (Bristol, UK). Stocks of all drugs or chemicals were diluted with the appropriate aCSF to the final concentration and applied by bath perfusion. In all experiments drugs were applied only after at least a 30-min control period, by which time all responses were stable.

\section{Results}

The results reported in this study were obtained from a total of 95 field recordings performed in the area CA1 of the rat hippocampus. Each slice was used only once. PS and epileptiform activities were all sensitive to TTX treatment applied at the end of selected experiments.

\section{Effects of E139 and NE on PS Recorded in Area CA1 of the Hippocampus}

The effects of various concentrations ( $1 \mathrm{nM}$ to $1 \mathrm{mM}$ ) of E139 were tested on the amplitude of the PS. At concentrations below $10 \mu \mathrm{M}, \mathrm{E} 139$ consistently depressed the amplitude of the PS. The threshold of PS depression was just above $100 \mathrm{nM}$ with a peak depression of $-23.9 \pm 2.3 \%$ $(\mathrm{p}<0.05 ; \mathrm{n}=6)$ recorded at $10 \mu \mathrm{M}$ (fig. 1a-c). Analysis of the initial rising slope of these same responses revealed that E139 $(10 \mu \mathrm{M})$ caused a depression of $-26.4 \pm 8.1 \%$ $(\mathrm{p}<0.05 ; \mathrm{n}=6$; fig. $1 \mathrm{~d})$. At $100 \mu \mathrm{M}$, the effects of E139 were mixed resulting in an average enhancement in the amplitude of the PS (fig. 1c). An even bigger enhancement was recorded at $1 \mathrm{mM}(60.1 \pm 35.6 \% ; \mathrm{n}=3$; fig. 1c). The effect of NE $(100 \mu \mathrm{M})$ on the PS amplitude and on the initial rising slope were also tested. Similar to $10 \mu \mathrm{M}$ E139, $100 \mu \mathrm{M}$ NE depressed these by $-34.5 \pm 6.0$ and
$-44.8 \pm 7.6 \%$, respectively $(\mathrm{p}<0.05 ; \mathrm{n}=8$; fig. $2 \mathrm{a}, \mathrm{b}$ and fig. 1d). This effect of NE showed substantial recovery $(>90 \%)$ following 10-20 min washout of NE. The NEinduced PS depression occluded E139 depression since in the presence of NE, $10 \mu \mathrm{M}$ E139 no longer produced a depression $(11.4 \pm 10.0 \% ; \mathrm{p}>0.05$ compared to the baseline amplitude in the presence of NE; $n=8$; fig. $2 a, b)$. UK $14304(1 \mu \mathrm{M})$, a selective $\alpha_{2}$-adrenoceptor agonist, also depressed the PS amplitude $(-32.6 \pm 9.4 \%$; $<<0.05 ; \mathrm{n}=$ 6; fig. 2b) to a similar extent as $100 \mu \mathrm{M} \mathrm{NE}$. It also occluded the ability of E139 to depress the PS amplitude (1.3 $\pm 0.5 \% ; \mathrm{p}>0.05$ compared to the baseline amplitude in the presence of UK 14304; fig. 2b). To further characterize this E139/NE interaction, we performed antagonism experiments. Pretreatment of slices with prazosin $(10 \mu \mathrm{M})$, an $\alpha_{1}$-adrenoceptor antagonist, did not prevent E139 (-24.8 $\pm 6.9 \% ; \mathrm{p}<0.05 ; \mathrm{n}=5$; fig. 3a) from depressing the PS amplitude, neither did it prevent NE from depressing the PS amplitude $(-29.7 \pm 6.1 \% ; \mathrm{p}<0.05 ; \mathrm{n}=5$; fig. 3a). By contrast, phentolamine $(10 \mu \mathrm{M})$, a non-selective $\alpha$-adrenoceptor antagonist, blocked the E139-induced PS depression ( $3.7 \pm 9.8 \% ; \mathrm{p}>0.05 ; \mathrm{n}=5$; fig. $3 \mathrm{~b}$ ). Furthermore, yohimbine $(1 \mu \mathrm{M})$, a selective $\alpha_{2}$-adrenoceptor antagonist, blocked both the NE-induced (5.7 \pm 8.2\%; $\mathrm{p}>0.05 ; \mathrm{n}=5)$ and E139-induced (5.1 \pm 5.9\%; $\mathrm{p}>$ $0.05 ; \mathrm{n}=6$ ) PS depression (fig. 3b).

\section{Effect of E139 and NE on Chemically Induced MS and $S B$}

In this in vitro model of seizure that targets and enhances glutamate-mediated excitatory transmission, when $\mathrm{Mg}^{2+}$ was removed from the perfusing buffer, the voltage-dependent $\mathrm{Mg}^{2+}$ block of $\mathrm{N}$-methyl-D-aspartate receptor was removed [29] leading to MS and SB. After recording in zero $\mathrm{Mg}^{2+}$ buffer for $20 \mathrm{~min}$, a single PS was transformed into MS (5.6 $\pm 0.3 ; \mathrm{n}=6$; $\mathrm{p}<0.05$; fig. $4 \mathrm{a})$ in response to a single electrical stimulation of the afferents. Similar to our previous report on E139 [5], NE $(100 \mu \mathrm{M})$ reversibly reduced the number of MS from $5.6 \pm 0.3$ to $3.8 \pm 0.2(-29.6 \pm 5.9 \% ; \mathrm{p}<0.05$; paired t test; $\mathrm{n}=6$; fig. $4 \mathrm{a}, \mathrm{b})$. The amplitude of the first spike was also reduced by $-28.1 \pm 6.0 \%(\mathrm{p}<0.05$; paired $\mathrm{t}$ test; $\mathrm{n}=6)$ in the presence of NE. When E139 $(10 \mu \mathrm{M})$ was applied at the peak of the NE effect, E139 produced a further decrease in the number of MS to $3.0 \pm 0.3(-28.2 \pm 1.8 \%$; $p<0.05$; $\mathrm{n}=6$; fig. 4a, b) without affecting the amplitude of the first spike $(-6.2 \pm 11.7 \% ; \mathrm{p}>0.05 ; \mathrm{n}=6$; fig. $4 \mathrm{a})$. Yohimbine $(1 \mu \mathrm{M})$ which by itself did not affect the number of MS (4.2 \pm 0.2 in control vs. $4.2 \pm 0.4$ in yohimbine; $\mathrm{p}>0.05 ; \mathrm{n}=$ 5 ; fig. 4c) blocked the effect of NE $(3.2 \pm 0.2 ; p>0.05$; 

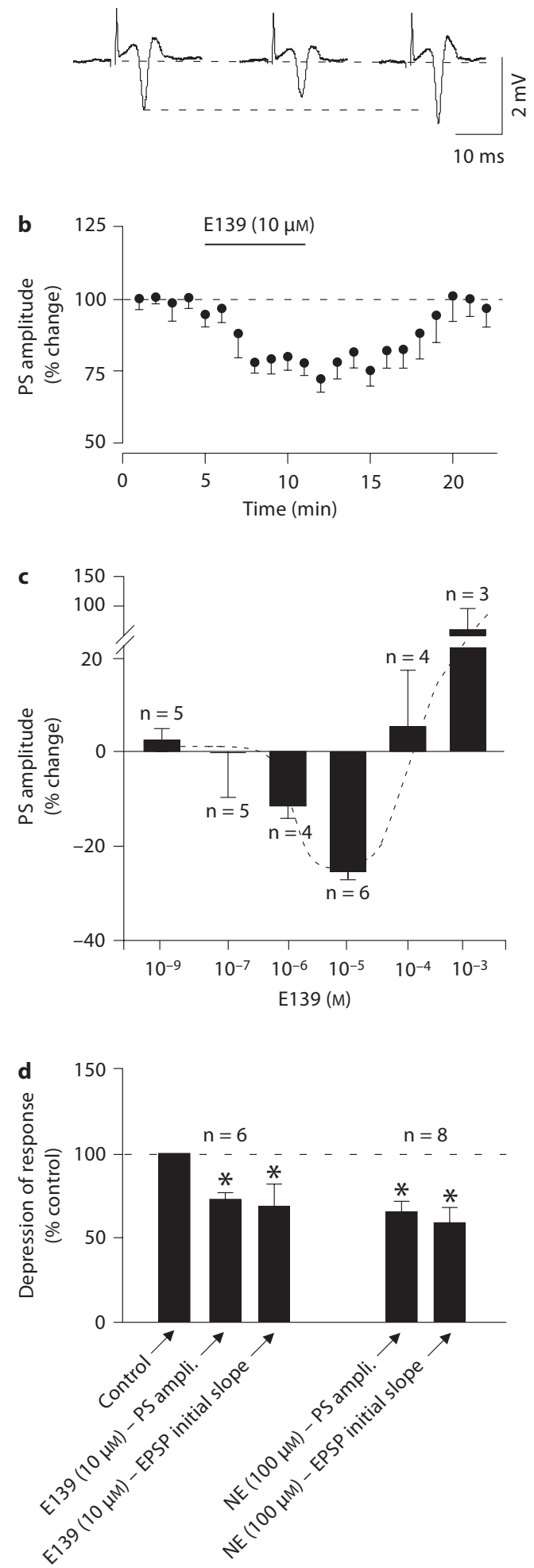
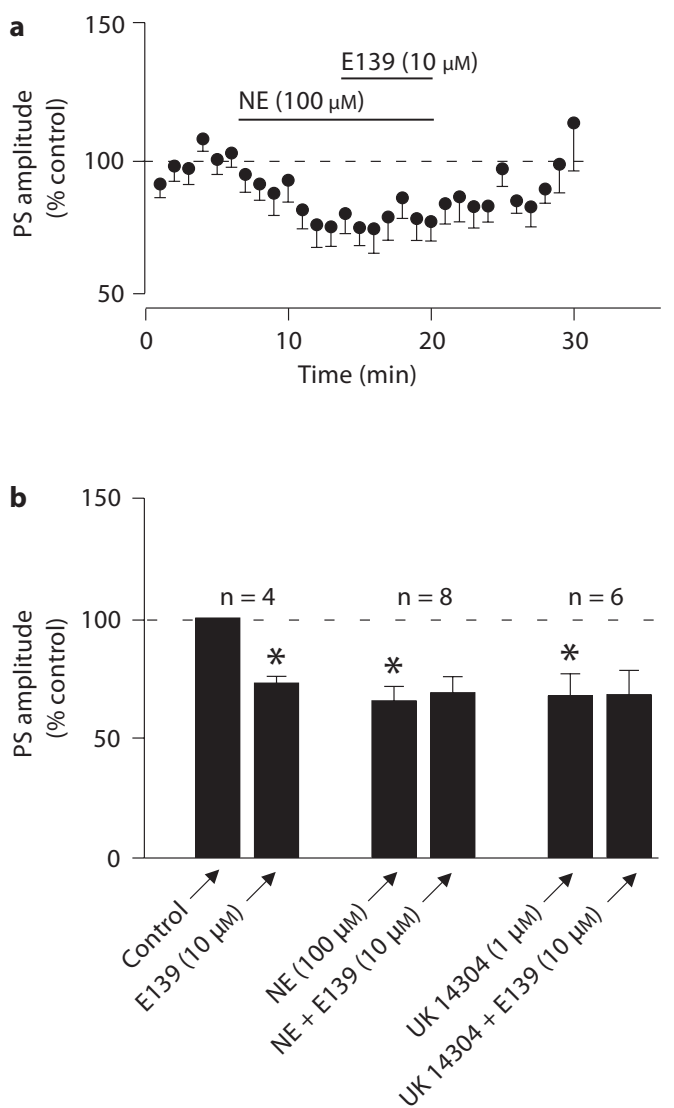

Fig. 1. E139 depresses evoked field PS in the CA1 region of the hippocampus in a concentration-dependent manner. a Sample PS recorded in the cell body layer of the area CA1 of the hippocampus in control, presence of $10 \mu \mathrm{M} \mathrm{E} 139$ and following $10 \mathrm{~min}$ washout of E139. b An average time-effect plot showing the effect of E139 on the PS amplitude obtained from 6 field recordings. c Concentration-response bar graph showing that E139 has a biphasic concentration-dependent effect on PS whereby concentrations of $10 \mu \mathrm{M}$ and below produce depression while $100 \mu \mathrm{M}$ and above enhance PS. $\mathbf{d}$ Average bar graph showing that the effects of E139 $(10 \mu \mathrm{M})$ and NE $(100 \mu \mathrm{M})$ on PS amplitude (ampli.) were similar to their effects on synaptic response as measured by the slope of the initial rising phase of the PS. ${ }^{*} \mathrm{p}<0.05$. EPSP $=\mathrm{Ex}-$ citatory postsynaptic potential. In this and all other figures, the number above/below each bar represents the number of slices to which each concentration/treatment was applied.

Fig. 2. NE inhibits PS amplitude that occludes E139 effects. a An average time-effect plot of the effect of NE $(100 \mu \mathrm{M})$ and that of E139 $(10 \mu \mathrm{M})$ in the continued presence of NE recorded in 8 slices. b Bar graphs summarizing the effects of $10 \mu \mathrm{M}$ E139 on PS amplitude (from fig. 1) and effects of NE alone and in combination with E139. Finally shown on the right of the graph are bars showing a similar inhibitory effect by UK 14304, a potent selective $\alpha_{2}$ adrenoceptor agonist, on PS amplitude and occlusion of the E139 effect. ${ }^{*} \mathrm{p}<0.05$ compared to control. 


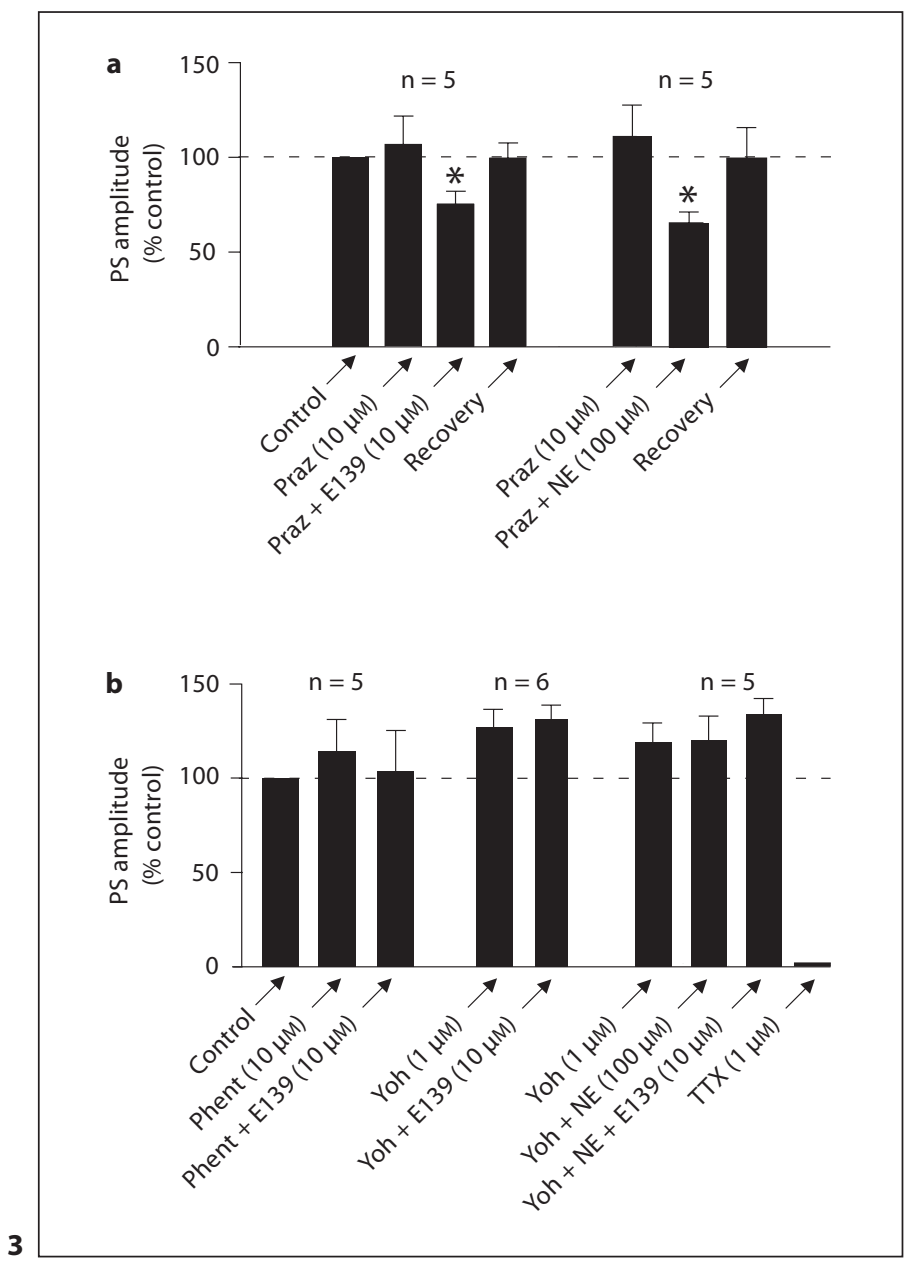

Fig. 3. NE- and E139-induced PS inhibitions are blocked by $\alpha$-adrenoceptor antagonists. a Summary bar graphs showing that both $\mathrm{NE}(\mathrm{n}=5)$ and E139 $(\mathrm{n}=5)$ are able to inhibit PS amplitude in the presence of prazosin (Praz), a selective $\alpha_{1}$-adrenoceptor antagonist. ${ }^{*} \mathrm{p}<0.05$. b By contrast to $\mathbf{a}$, phentolamine (Phent; $\mathrm{n}=5$ ), a non-selective $\alpha$-adrenoceptor antagonist, and yohimbine (Yoh; $n=6$ ), a selective $\alpha_{1}$-adrenoceptor antagonist, both blocked the NE- and E139-induced PS amplitude inhibition. Also shown here is the effect of TTX $(1 \mu \mathrm{M} ; \mathrm{n}=5)$ on PS.

Fig. 4. NE inhibits multiple PS frequency that does not occlude the effect of E139. a Sample traces of a PS (first) and multiple PS (next 3 traces) induced by zero $\mathrm{Mg}^{2+}$ buffer and the effect of $\mathrm{NE}$ $(100 \mu \mathrm{M})$ alone and in the presence of E139 $(10 \mu \mathrm{M})$ on the frequency of multiple PS. Note the depression of the first spike by NE without any further depression by E139 and the total elimination of the spikes by TTX. b Summary bar graphs $(n=6)$ showing the effect of zero $\mathrm{Mg}^{2+}$ on the number of spikes triggered by a single afferent stimulation and the effect of $\mathrm{NE}$ alone and subsequently $\mathrm{NE}+$ E139. ${ }^{\mathrm{a}} \mathrm{p}<0.05$ compared to control, ${ }^{\mathrm{b}} \mathrm{p}<0.05$ compared to zero $\mathrm{Mg}^{2+},{ }^{\mathrm{c}} \mathrm{p}<0.05$ compared to zero $\mathrm{Mg}^{2+}+\mathrm{NE}$. Note that the effect of E139 alone on PS numbers has been inserted for comparison (modified from Ananthalakshmi et al. [5]). c Summary bar graph $(\mathrm{n}=5)$ showing that yohimbine (Yoh) blocked NE- and E139-induced depression of the frequency of MS.

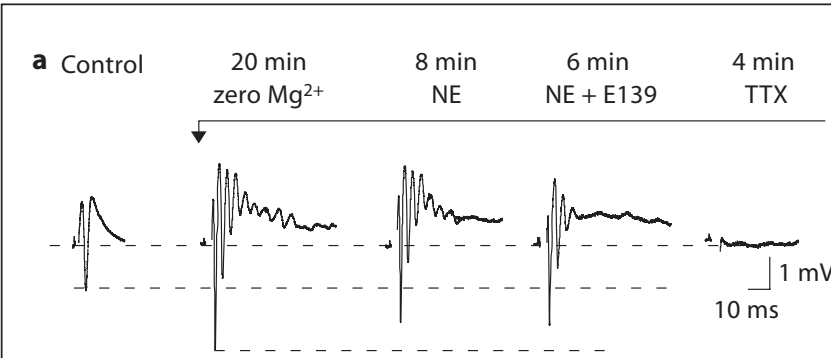

b
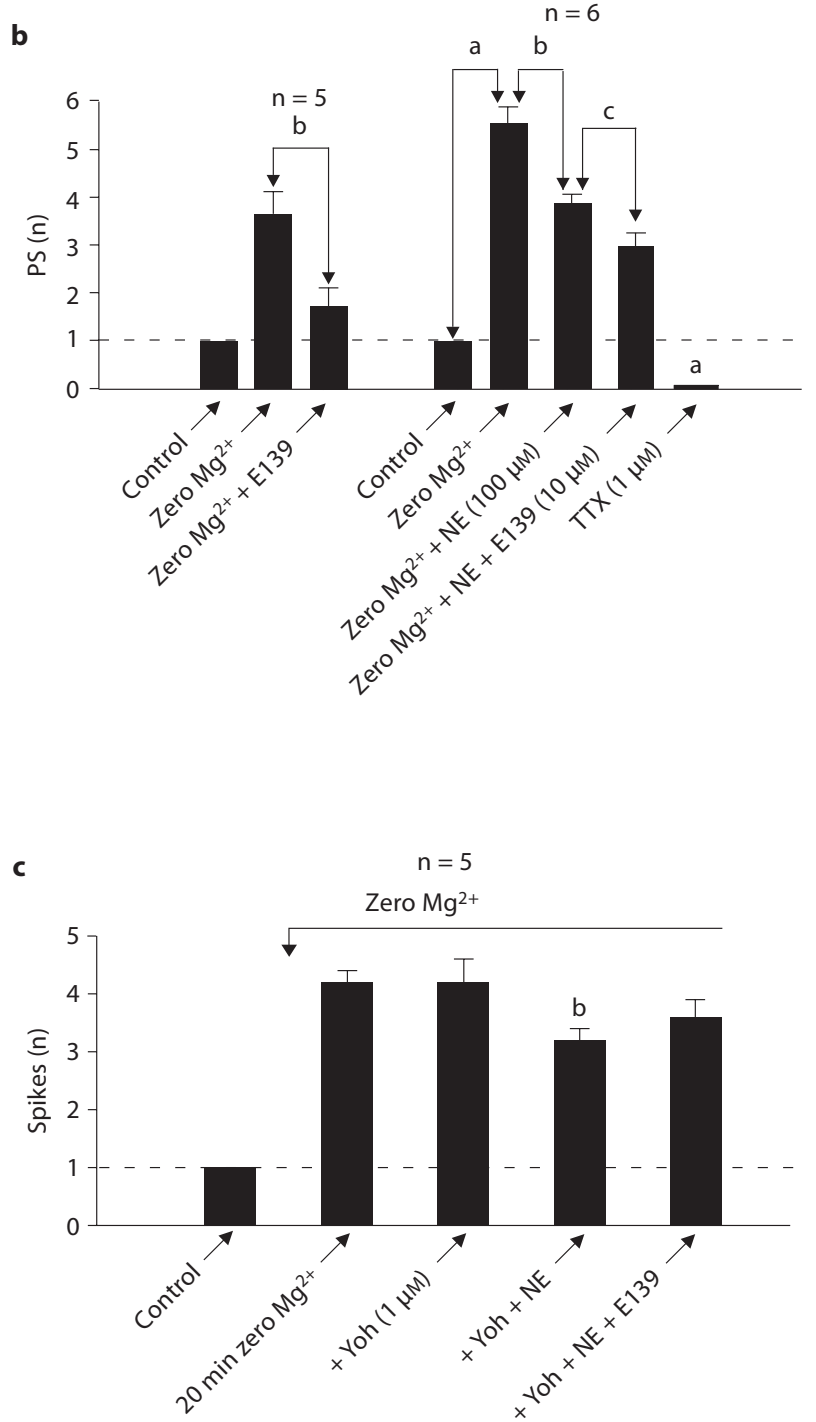


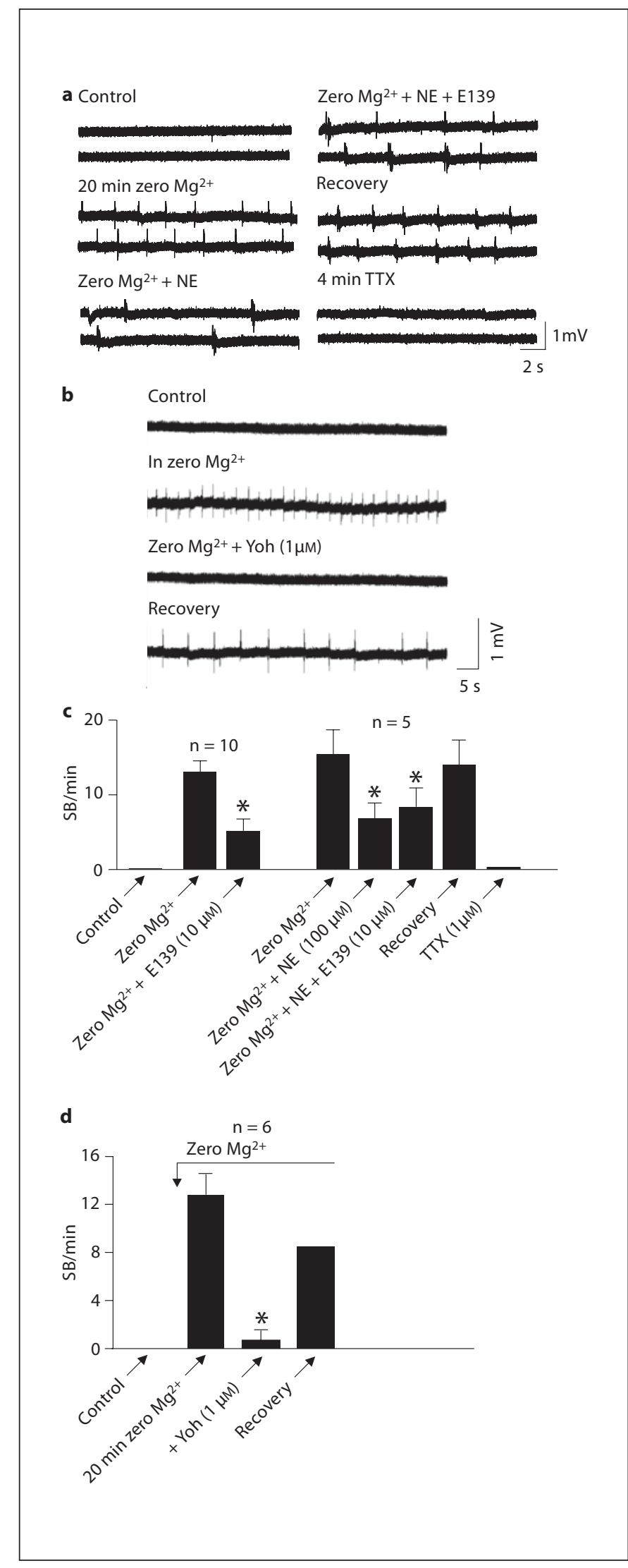

$\mathrm{n}=5$; fig. 4c). Furthermore it also blocked the E139 effect on the number of MS when it was applied in the presence of NE (3.6 $\pm 0.3 ; p>0.05 ; n=5$; fig. 4c). An application for 15-20 min of zero $\mathrm{Mg}^{2+}$ buffer induced SB that ranged in frequency from 5 to $20 / \mathrm{min}$ yielding a mean of $15.4 \pm$ $3.3 / \mathrm{min}(\mathrm{p}<0.05 ; \mathrm{n}=5$; fig. $5 \mathrm{a}-\mathrm{d})$. NE $(100 \mu \mathrm{M})$ reduced this frequency to $6.8 \pm 2.1 / \mathrm{min}$, a depression of $-60.8 \pm$ $11.7 \%(\mathrm{p}<0.05 ; \mathrm{n}=5$; fig. 5a, c). Application of E139 at the peak of this NE effect did not produce any further reduction in SB frequency (16.2 $\pm 12.7 \% ; \mathrm{p}>0.05 ; \mathrm{n}=5$; fig. $5 \mathrm{a}$, c). SB had an average duration of $108.7 \pm 9.3 \mathrm{~ms}$ and contained $9.9 \pm 1.6$ spikes $(\mathrm{p}<0.05 ; \mathrm{n}=10)$. Further analyses of SB in the presence of E139 and NE revealed that they suppressed both the duration of SB (-57.1 \pm 18.1 and $-66.1 \pm 11.3 \%$, respectively) and the number of spikes in each SB $(-74.0 \pm 7.5$ and $-55.8 \pm 7.5 \%$, respectively; $\mathrm{p}<$ $0.05, \mathrm{n}=5$ each) to a similar extent.

In another set of experiments to verify the pharmacology of the effects of NE and E139 on SB, bath application of yohimbine $(1 \mu \mathrm{M})$ almost completely abolished the SB frequency, reducing it from $12.8 \pm 1.7$ to $0.7 \pm 0.8 / \mathrm{min}$, a suppression of $-94.5 \pm 11.7 \%(\mathrm{p}<0.05 ; \mathrm{n}=6$; fig. $5 \mathrm{~b}$, d). This effect was about $85 \%$ reversible upon washing out of yohimbine (fig. 5b, d).

\section{Discussion}

In this study, we investigated a possible interaction between E139 and NE on population responses in a chemically induced in vitro seizure model. Our data on fieldrecorded PS whereby both NE and E139 suppressed the amplitude that mutually occluded each other are consistent with our previous finding in single-cell studies [6]. Analyses of the synaptic component (initial rising phase) of the PS indicate that suppression of this phase contributed the most to the entire PS suppression since for both

Fig. 5. NE inhibits SB frequency that occludes the effect of E139. a Sample traces showing SB induced by zero $\mathrm{Mg}^{2+}$ and the effect of NE alone and E139 in the presence of NE. All SB were eliminated by TTX $(1 \mu \mathrm{M})$. b Sample traces showing SB induced by zero $\mathrm{Mg}^{2+}$ and the effect of Yoh $(1 \mu \mathrm{M})$ on the SB. c Summary bar graphs $(n=5)$ showing the effect of zero $\mathrm{Mg}^{2+}$ on the number of $\mathrm{SB}$ and the effect of NE alone and, subsequently, NE + E139. Note that the effect of E139 alone on SB/min has been inserted for comparison (modified from Ananthalakshmi et al. [5]). d Summary bar graph $(\mathrm{n}=6)$ showing that yohimbine (Yoh) reversibly suppresses zero- $\mathrm{Mg}^{2+}$-induced SB. ${ }^{*} \mathrm{p}<0.05$ compared to zero $\mathrm{Mg}^{2+}$. 
$\mathrm{NE}$ and E139, the latter suppression was not significantly different from the suppression of the initial rising phase. This suggests that the compound action potential is tightly coupled to the synaptic response that drives the action potentials. Furthermore, the pharmacology of these actions (mimicry by UK 14304 and blockade by phentolamine and yohimbine) also point to the involvement of a similar mechanism in suppressing the population spike in the hippocampus, i.e. both E139 and NE appear to produce their suppressant effects through action on $\alpha_{2}$-adrenoceptors which have been reported to mediate the anticonvulsant effects of NE [12, 18, 33, 34]. Consistent with previous reports on the anticonvulsant actions of NE [16, 18 , 35-37], it suppressed the MS frequency and SB. Interestingly, unlike their mutually occlusive actions on PS amplitude, the presence of NE did not prevent E139 from further suppressing the MS frequency. This effect of E139 in the presence of NE may be due to the fact that E139, in addition to employing adrenergic mechanisms to suppress neuronal activity, also has direct effects on sodium channels [4]. Thus, the non-adrenergic component of this action of E139 may be related to its effect on postsynaptic sodium channels.

Similar to its blockade of NE and E139 effects on PS, yohimbine also blocked the MS frequency suppression by $\mathrm{NE}$ and E139. Also, the suppression of SB by NE occluded that of E139 further implicating an adrenergic mechanism. Finally, contrary to expectation, yohimbine almost completely wiped out the SB suggesting that NE, possibly acting on a subtype of $\alpha_{2}$-adrenoceptor [16, 34, 38], may promote epileptogenesis, i.e. have proconvulsant effects. Pro- and anticonvulsant effects of NE acting on $\alpha_{2}$-adrenoceptors have been reported to be mediated by distinct populations of the same subtype of $\alpha_{2}$-adrenoceptors $\left(\alpha_{2} \mathrm{~A}\right)$ located on presynaptic or postsynaptic sites [16]. Alternatively, the apparent anticonvulsant effect of yohimbine observed here may be due to its reported partial agonist action on some serotonin receptors [39]. Such a postulated serotoninergic action of yohimbine on epileptiform activity in the hippocampus needs to be critically examined in future studies.

\section{Conclusion}

The results of this study reveal that E139, a prototypical anilino-enaminone, suppresses chemically induced in vitro epileptiform activity via both adrenergic and non-adrenergic mechanisms. These findings support the hypothesis that E139 may employ multiple mechanisms to produce its anticonvulsant effects.

\section{Acknowledgements}

Grant No. PT02/02 from Kuwait University to S.B.K. supported this work. We thank Prof M.A. Oriowo for the generous gift of norepinephrine, UK 14304 and yohimbine.

\section{References}

1 Edafiogho IO, Hinko CN, Chang H, Moore JA, Mulzac D, Nicholson JM, Scott KR: Synthesis and anticonvulsant activity of enaminones. J Med Chem 1992;35:2798-2805.

2 Mulzac D, Scott KR: Profile of anticonvulsant activity and minimal toxicity of methyl 4-[(p-chlorophenyl)amino]-6-methyl-2oxocyclohex-3-en-1-oate and some prototype antiepileptic drugs in mice and rats. Epilepsia 1993;34:1141-1146.

-3 Kombian SB, Edafiogho IO, Ananthalakshmi KVV: Anticonvulsant enaminones depress excitatory synaptic transmission in the rat brain by enhancing extracellular GABA levels. Br J Pharmacol 2005;145:945-953.

4 Ananthalakshmi KVV, Edafiogho IO, Kombian SB: Concentration-dependent effects of anticonvulsant enaminone methyl 4-(4'-bromophenyl)aminocyclohex-3-en-6-methyl2-oxo-1-oate on neuronal excitability in vitro. Neuroscience 2006;141:345-356.
5 Ananthalakshmi KVV, Edafiogho IO, Kombian SB: Anticonvulsant enaminone E139 suppresses epileptiform activity in rat hippocampal slices. Epilepsy Res 2007;76:8592.

-6 Kombian SB, Ananthalakshmi KVV, Edafiogho IO: Enaminones and norepinephrine employ convergent mechanisms to depress excitatory synaptic transmission in the rat nucleus accumbens in vitro. Eur J Neurosci 2006;24:2781-2788.

7 Mody I, Leung P, Miller JJ: Role of norepinephrine in seizure-like activity of hippocampal pyramidal cells maintained in vitro: alteration by 6-hydroxydopamine lesions of norepinephrine-containing systems. Can J Physiol Pharmacol 1983;61:841-846.
-8 Lindvall O, Barry DI, Kikvadze I, Brundin P, Bolwig TG, Bjorklund A: Intracerebral grafting of fetal noradrenergic locus coeruleus neurons: evidence for seizure suppression in the kindling model of epilepsy. Prog Brain Res 1988;78:79-86.

9 Weiss GK, Lewis J, Jimenez-Rivera C, Vigil A, Corcoran ME: Antikindling effects of locus coeruleus stimulation: mediation by ascending noradrenergic projections. Exp Neurol 1990;108:136-140.

10 Szot P, Weinshenker D, White SS, Robbins CA, Rust NC, Schwartzkroin PA, Palmiter RD: Norepinephrine-deficient mice have increased susceptibility to seizure-inducing stimuli. J Neurosci 1999;19:10985-10992.

11 Weinshenker D, Szot P: The role of catecholamines in seizure susceptibility: new results using genetically engineered mice. Pharmacol Ther 2002;94:213-233. 
\12 Giorgi FS, Pizzanelli C, Biagioni F, Murri L, Fornai F: The role of norepinephrine in epilepsy: from the bench to the bedside. Neurosci Biobehav Rev 2004;28:507-524.

-13 Schank JR, Liles LC, Weinshenker D: Reduced anticonvulsant efficacy of valproic acid in dopamine beta-hydroxylase knockout mice. Epilepsy Res 2005;65:23-31.

14 Kaminski RM, Shippenberg TS, Witkin JM, Rocha BA: Genetic deletion of the norepinephrine transporter decreases vulnerability to seizures. Neurosci Lett 2005;382:5155.

$>15$ Giorgi FS, Lazzeri G, Natale G, Iudice A, Ruggieri S, Paparelli A, Murri L, Fornai F: MDMA and seizures: a dangerous liaison? Ann NY Acad Sci 2006;1074:357-364.

-16 Szot P, Lester M, Laughlin ML, Palmiter RD, Liles LC, Weinshenker D: The anticonvulsant and proconvulsant effects of alpha2adrenoreceptor agonists are mediated by distinct populations of alpha2A-adrenoreceptors. Neuroscience 2004;126:795-803.

17 Rutecki PA: Noradrenergic modulation of epileptiform activity in the hippocampus. Epilepsy Res 1995;20:125-136.

$\checkmark 18$ Jurgens CW, Boese SJ, King JD, Pyle SJ, Porter JE, Doze VA: Adrenergic receptor modulation of hippocampal CA3 network activity. Epilepsy Res 2005;66:117-128.

$\checkmark 19$ Corcoran ME, Fibiger HC, McCaughran JA Jr, Wada JA: Potentiation of amygdaloid kindling and metrazol-induced seizures by 6 hydroxydopamine in rats. Exp Neurol 1974; 45:118-133.

20 McIntyre DC: Amygdala kindling in rats: facilitation after local amygdala norepinephrine depletion with 6-hydroxydopamine. Exp Neurol 1980;69:395-407.

-21 Wu HQ, Tullii M, Samanin R, Vezzani A: Norepinephrine modulates seizures induced by quinolinic acid in rats: selective and distinct roles of alpha-adrenoceptor subtypes. Eur J Pharmacol 1987;138:309-318.

-22 McIntyre DC, Giugno L: Effect of clonidine on amygdala kindling in normal and 6-hydroxydopamine-pretreated rats. Exp Neurol 1988;99:96-106.
23 Stringer JL, Lothman EW: Cholinergic and adrenergic agents modify the initiation and termination of epileptic discharges in the dentate gyrus. Neuropharmacology 1991;30: 59-65.

24 Janumpalli S, Butler LS, MacMillan LB, Limbird LE, McNamara JO: A point mutation $(\mathrm{D} 79 \mathrm{~N})$ of the alpha2A adrenergic receptor abolishes the antiepileptogenic action of endogenous norepinephrine. J Neurosci 1998; 18:2004-2008.

25 Kunieda T, Zuscik MJ, Boongird A, Perez DM, Luders HO, Najm IM: Systemic overexpression of the alpha $1 \mathrm{~B}$-adrenergic receptor in mice: an animal model of epilepsy. Epilepsia 2002;43:1324-1329.

26 Klapstein GJ, Colmers WF: Neuropeptide Y suppresses epileptiform activity in rat hippocampus in vitro. J Neurophysiol 1997;78: 1651-1661.

27 Motamedi GK, Salazar P, Smith EL, Lesser RP, Webber WR, Ortinski PI, Vicini S, Rogawski MA: Termination of epileptiform activity by cooling in rat hippocampal slice epilepsy models. Epilepsy Res 2006;70:200210.

28 Pralong E, Magistretti PJ: Noradrenaline increases $\mathrm{K}$-conductance and reduces glutamatergic transmission in the mouse entorhinal cortex by activation of alpha 2adrenoreceptors. Eur J Neurosci 1995;7: 2370-2378.

29 Mayer ML, Westbrook GL: Permeation and block of N-methyl-D-aspartic acid receptor channels by divalent cations in mouse cultured central neurones. J Physiol 1987;394: 501-527.

30 Anderson WW, Lewis DV, Swartzwelder HS, Wilson WA: Magnesium-free medium activates seizure-like events in the rat hippocampal slice. Brain Res 1986;398:215-219.

-31 Gean PW, Shinnick-Gallagher P: Epileptiform activity induced by magnesium-free solution in slices of rat amygdala: antagonism by N-methyl-D-aspartate receptor antagonists. Neuropharmacology 1988;27: 557-562.

-32 Edafiogho IO, Denny BJ, Schwalbe CH, Lowe PR: X-ray crystallographic and theoretical studies of an anticonvulsant enaminone: methyl 4-(4'-bromophenyl)amino-6-methyl-2-oxocyclohex-3-en-1-oate. Med Princ Pract 2003;12:237-242.
33 Shouse MN, Langer J, Bier M, Farber PR, Alcalde O, Moghimi R, Richkind M, Szymusiak R: The alpha 2 adrenoreceptor agonist clonidine suppresses seizures, whereas the alpha 2 adrenoreceptor antagonist idazoxan promotes seizures: pontine microinfusion studies of amygdala-kindled kittens. Brain Res 1996;731:203-207.

34 Jurgens CW, Hammad HM, Lichter JA, Boese SJ, Nelson BW, Goldenstein BL, Davis KL, Xu K, Hillman KL, Porter JE, Doze VA: Alpha2A adrenergic receptor activation inhibits epileptiform activity in the rat hippocampal CA3 region. Mol Pharmacol 2007;71: 1572-1581.

-35 Stoop R, Epiney S, Meier E, Pralong E: Modulation of epileptiform discharges in the rat limbic system in vitro by noradrenergic agents. Neurosci Lett 2000;287:5-8.

36 Weinshenker D, Szot P, Miller NS, Rust NC, Hohmann JG, Pyati U, White SS, Palmiter RD: Genetic comparison of seizure control by norepinephrine and neuropeptide Y. J Neurosci 2001;21:7764-7769.

37 Weinshenker D, Szot P, Miller NS, Palmiter RD: Alpha(1) and beta(2) adrenoreceptor agonists inhibit pentylenetetrazole-induced seizures in mice lacking norepinephrine. J Pharmacol Exp Ther 2001;298:1042-1048.

- 38 Renouard A, Widdowson PS, Millan MJ: Multiple alpha 2 adrenergic receptor subtypes. I. Comparison of $\left[{ }^{3} \mathrm{H}\right] \mathrm{RX} 821002-\mathrm{la}-$ beled rat $\mathrm{R}$ alpha-2A adrenergic receptors in cerebral cortex to human $\mathrm{H}$ alpha2A adrenergic receptor and other populations of alpha-2 adrenergic subtypes. J Pharmacol Exp Ther 1994;270:946-957.

39 Millan MJ, Newman-Tancredi A, Audinot V, Cussac D, Lejeune F, Nicolas JP, Coge F, Galizzi JP, Boutin JA, Rivet JM, Dekeyne A, Gobert A: Agonist and antagonist actions of yohimbine as compared to fluparoxan at alpha(2)-adrenergic receptors (AR)s, serotonin $(5-\mathrm{HT})(1 \mathrm{~A}), 5-\mathrm{HT}(1 \mathrm{~B}), 5-\mathrm{HT}(1 \mathrm{D})$ and dopamine $\mathrm{D}(2)$ and $\mathrm{D}(3)$ receptors: significance for the modulation of frontocortical monoaminergic transmission and depressive states. Synapse 2000;35:79-95. 